NATALIA ZIMNIEWICZ

Poznań

\title{
Wpływ zjawisk ekonomicznych na zaburzenia procesów informowania o dzialaniu i skuteczności antykoncepcji hormonalnej
}

W 1960 roku na rynek amerykański wprowadzono doustną pigułkę antykoncepcyjną, co przyczyniło się do wybuchu rewolucji seksualnej. Kościół był w tamtym okresie pod ogromną presją mediów i innych środowisk próbujących wymóc na nim akceptację dla nowych produktów. Papież Paweł VI oparł się jednak tym naciskom. W wydanej 25 lipca 1968 roku encyklice Humanae vitae o zasadach moralnych w dziedzinie przekazywania życia ludzkiego zalecił zdecydowanie, aby „każdy akt małżeński zachował swoje wewnętrzne przeznaczenie do przekazywania życia ludzkiego" (HV 11). Choć dopuszczał naturalną regulację poczęć, to zabronione zostało jakiekolwiek działanie o charakterze antykoncepcyjnym i wczesnoporonnym (HV 14, 17). Decyzja ta wzbudziła wiele głosów sprzeciwu. Niezrozumienie decyzji papieża trwa do dziś, także w samym Kościele.

Obrońcy Humanae vitae mówią z kolei, że papież ogłoszony w 2018 roku świętym miał specjalne natchnienie, niezrozumiałą dla ludzi swoich czasów intuicję. Po wielu latach od tamtych wydarzeń wychodzą na jaw liczne fakty, które nie były wcześniej wystarczająco tłumaczone.

\section{Tajemnicza zmiana definicji pojęcia „ciąża”}

W latach 60. miało miejsce jeszcze inne znaczące wydarzenie, rozumiane dziś lepiej niż w tamtych czasach. W 1965 roku, krótko po wprowadzeniu pigułki antykoncepcyjnej na rynek, Światowa Organizacja Zdrowia (WHO) zmieniła definicję ciąży. W ślad za nią podobnej modyfikacji dokonało Ame- 
rykańskie Towarzystwo Położnictwa i Ginekologii. Wcześniej ciąża była określana jako czas od zapłodnienia do porodu. Według nowego ujęcia ciąża rozpoczyna się od momentu udanej implantacji, a więc około 6-11 dni od poczęcia (Jarczewska [red.] 2015, s. IX-X).

Definicja terminu „ciąża” wpływa bezpośrednio na rozumienie pojęć „wczesne poronienie”, „wczesna aborcja” czy „środki wczesnoporonne”. W poprzednim ujęciu każde obumarcie zapłodnionej komórki jajowej byłoby nazwane wczesnym poronieniem. Po zmianie definicji poronieniem można nazwać tylko te przypadki, w których wcześniej nastąpiła implantacja w macicy kobiety.

Rysunek 1 pokazujący układ rozrodczy kobiety pomaga wyjaśnić ten problem. Zapłodnienie, czyli połączenie komórki jajowej z plemnikiem, następuje na końcu jajowodów. Zapłodniona komórka jajowa dzieli się i rozwija, przemieszczając się w kierunku macicy. Dopiero po 6-11 dniach następuje implantacja, czyli zagnieżdżenie w macicy, do czego niezbędne jest odpowiednio przygotowane endometrium, czyli błona śluzowa macicy.

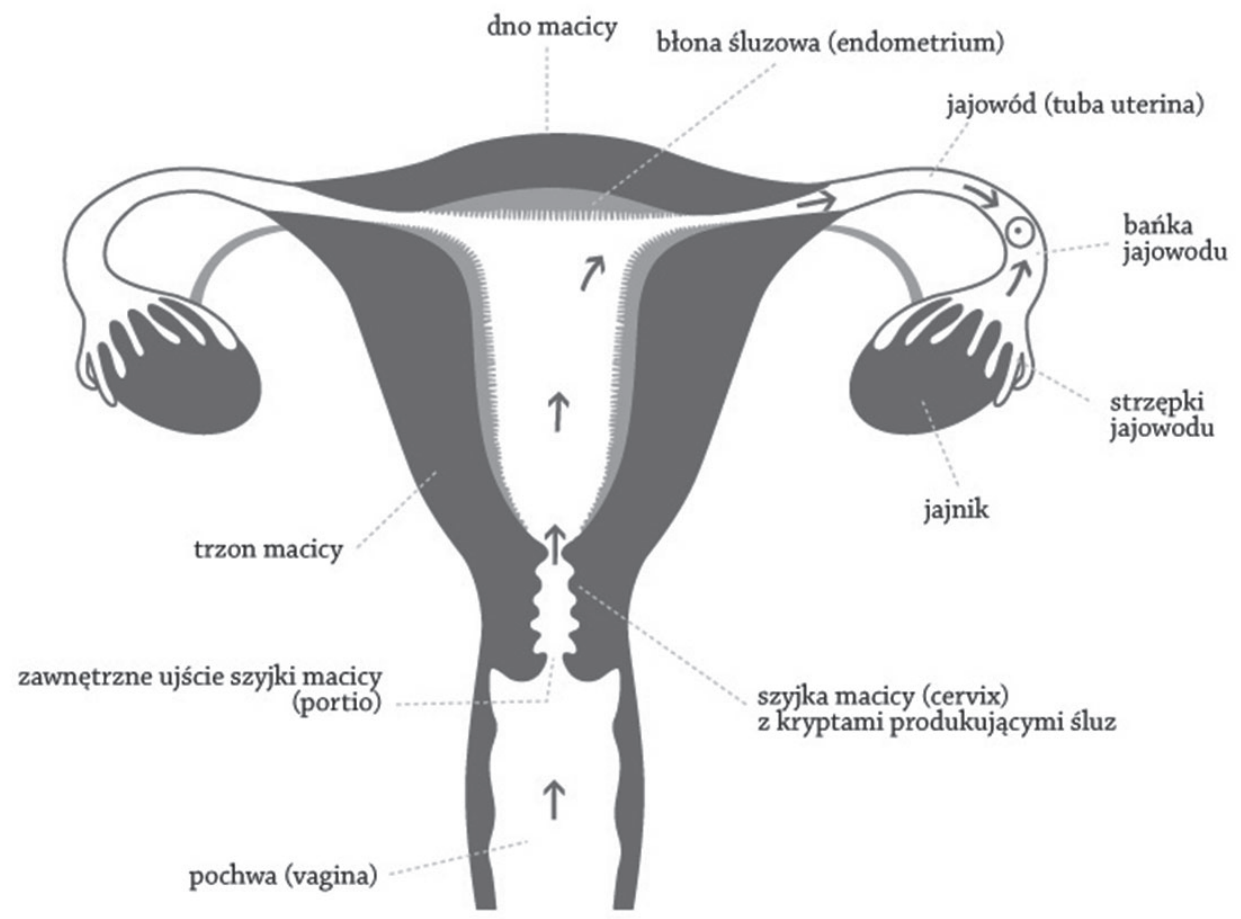

Rysunek 1. Układ rozrodczy kobiety

Źródło: www.myfertiledays.com 
Istnieją zatem równolegle dwie definicje ciąży i pojęć odnoszących się do jej przerwania. Obie są stosowane zamiennie, co jest rzadko thumaczone. Wzmaga to wrażenie obiektywizmu przekazu i zaufanie kobiet do uspokajającego przekazu na temat działania antykoncepcji hormonalnej.

Obydwa sposoby rozumienia terminu „ciąża” i pojęć odnoszących się do jej przerwania współistnieją ze sobą we współczesnym zastosowaniu. Przykładowo na ulotkach testów ciążowych czy na portalach internetowych dla kobiet oczekujących narodzin dziecka opisujących etapy rozwoju dziecka ciąża jest przedstawiana jako stan zaczynający się od momentu poczęcia. W materiałach poświęconych promocji antykoncepcji hormonalnej początek ciąży ukazuje się jako moment zagnieżdżenia. Pojęcie ,antykoncepcja” oznacza dosłownie „przeciwpoczęcie”. W języku angielskim conception oznacza 'poczęcie'1. Sama nazwa, a także większość sposobów opisu i prezentacji tych substancji wprowadzają w błąd konsumentów. Odmienne znaczenia tego samego pojęcia są stosowane zamiennie, co prawie nigdzie nie jest tłumaczone.

Analiza sposobu informacyjnego na temat tej antykoncepcji pozwala na obserwację, że różne grupy interesu próbują ukrywać przed społeczeństwem omawiany dualizm pojęciowy oraz prawdziwe działanie wspomnianych środków. Informacje na ulotkach poświęconych antykoncepcji hormonalnej czy w mediach mainstreamowych traktują ten temat niejasno i mętnie (por. Prusak 2015, s. 37-43).

\section{Prawdziwe działanie antykoncepcji hormonalnej}

Wiele dziesiątków lat zajęło odkrycie prawdziwego działania antykoncepcji hormonalnej. Liczne, ale słabo nagłaśniane badania naukowe, a także enigmatyczne opisy na ulotkach pozwalają nakreślić obraz prawdziwego działania tego wynalazku. Świat medycyny nie zaprzecza tym danym lub je potwierdza, ale walczy ze wszystkimi, którzy je publicznie nagłaśniają. Propagują je głównie środowiska związane z Kościołem. Często są to tak zwani lekarze i farmaceuci sumienia.

Prawdziwe działanie pigułki antykoncepcyjnej obejmuje kilka mechanizmów (por. Jarczewska, Barczentewicz 2015, s. 3-36):

1) Hamowanie owulacji. Jest to działanie przeciwpoczęciowe, które zapobiega połączeniu komórki jajowej z plemnikiem. Jednakże jego skuteczność jest bardzo niewielka i dlatego o ostatecznym efekcie decydują pozostałe sposoby działania tego typu antykoncepcji. Nawet przy

\footnotetext{
${ }^{1} \mathrm{https}: / /$ pl.pons.com/t\% $\% 5 \% 82$ umaczenie?q=conception\&l=enpl\&in=\&lf=en [dostęp: 01.09.2018].
} 
perfekcyjnym użyciu owulacje zdarzają się z częstością rzędu 12-30\% w przypadku pigułki dwuskładnikowej. Oznacza to, że na 100 kobiet używających pigułki w każdym cyklu 12-30 z nich ma owulację. W przypadku pigułki gestagennej jednoskładnikowej (minipigułki) owulacje występują nawet w $60-80 \%$. W każdym cyklu 60-80 kobiet na 100 ma zatem owulację. Tak wysoki odsetek owulacji połączony ze swobodnym współżyciem seksualnym skutkuje zapłodnieniem i poczęciem dziecka. U większości z takich kobiet ciąża maciczna się nie rozwija, ponieważ działają inne opisane poniżej pozapłodnieniowe mechanizmy pigułki antykoncepcyjnej.

2) Zagęszczenie śluzu wydzielanego w szyjce macicy. Ma to na celu utrudnienie przedostawania się plemników do jajowodów. Jak pokazują badania, przeciwpoczęciowy wpływ tego mechanizmu jest jednak słaby. Plemniki pomimo wszystko przedostają się do jajowodów kobiety i - napotykając na komórkę jajową w czasie owulacji - powodują jej zapłodnienie.

3) Wpływ na endometrium, czyli błonę śluzową macicy, w której zagnieżdża się zarodek. Pod wpływem hormonów endometrium w macicy staje się cieńsze, zanikowe, ma zmienioną strukturę. W badaniach nad zapłodnieniem in vitro udowodniono, że minimalna grubość błony śluzowej macicy do utrzymania ciąży wynosi $7 \mathrm{~mm}$. Maksymalną liczbę ciąż obserwowano przy endometrium o grubości 8-10 mm. U kobiet stosujących antykoncepcję hormonalną endometrium zazwyczaj ma grubość poniżej $5 \mathrm{~mm}$. Dochodzi także do zmian na poziomie molekularnym oraz mikroskopowym. Poczęte dziecko po podróży przez jajowód i po dotarciu do macicy nie ma się gdzie zagnieździć i na skutek tego umiera.

Jeżeli dochodzi do owulacji nawet u 30\% kobiet (i nawet u 80\% stosujących minitabletki), to u wielu z nich przy swobodnym współżyciu najprawdopodobniej dochodzi do poczęcia dziecka. U większości z nich nie obserwuje się normalnej ciąży, ponieważ poczęte dziecko po podróży przez jajowód, po dotarciu do macicy nie ma się gdzie zagnieździć i na skutek tego obumiera (por. Jarczewska 2015, s. 2).

Oprócz zmian w endometrium na poczęte dziecko mogą działać także inne, słabo poznane, ale bardzo prawdopodobne mechanizmy działające po zapłodnieniu, takie jak np. spowolnienie perystaltyki jajowodów i spowolnienie ruchów rzęsek nabłonka jajowodu. Mechanizmy te utrudniają i opóźniają transport zarodka do macicy, wskutek czego ginie on przed dotarciem do celu (por. Jarczewska 2015, s. 2). 


\section{Badanie świadomości społecznej dotyczącej prawdziwego dzialania antykoncepcji hormonalnej}

Na podstawie powyższych analiz powstało pytanie, na ile społeczeństwo jest świadome prawdziwego działania antykoncepcji hormonalnej. W tym celu w styczniu 2014 roku przeprowadzone zostało badanie na ogólnopolskiej próbie losowej, reprezentatywnej dla dorosłych mieszkańców Polski. Tabela 1 prezentuje notę metodologiczną tego badania.

Tabela 1. Nota metodologiczna badania

\begin{tabular}{|l|l|}
\hline \multicolumn{1}{|c|}{ Wykonawca badania } & \multicolumn{1}{c|}{ Centrum Badania Opinii Społecznej } \\
\hline $\begin{array}{l}\text { Termin realizacji badania } \\
\text { (praca ankieterów w terenie) }\end{array}$ & Od 16 do 26 stycznia 2014 roku \\
\hline Rodzaj badania & Ilościowe typu omnibus \\
\hline Rodzaj próby & $\begin{array}{l}\text { Ogólnopolska, losowa PESEL reprezentatywna dla } \\
\text { dorosłych mieszkańców Polski }\end{array}$ \\
\hline $\begin{array}{l}\text { Próba zrealizowana (liczba } \\
\text { przeprowadzonych wywiadów) }\end{array}$ & 1046 \\
\hline Metoda przeprowadzenia wywiadów & $\begin{array}{l}\text { Bezpośredni wywiad ankieterski wspomagany } \\
\text { komputerowo (Computer Assisted Personal } \\
\text { Interviewing - w skrócie CATI) }\end{array}$ \\
\hline Miejsce przeprowadzenia wywiadów & W domu wylosowanej osoby. \\
\hline
\end{tabular}

Zadane w wywiadzie pytania miały na celu sprawdzenie sposobu rozumienia działania antykoncepcji hormonalnej, a także sprawdzenie stopnia wrażliwości na informacje o działaniu wczesnoporonnym. Tabele 2-11 prezentują zadane pytania i udzielane odpowiedzi.

Prawidłowa jest tylko pierwsza odpowiedź na to pytanie. Zakreśliło ją jedynie $19,7 \%$ respondentów. Wyłącznie powstrzymanie owulacji może zapobiec połączeniu komórki jajowej z plemnikiem. Wszystkie inne wymienione odpowiedzi są nieprawidłowe. Zagęszczenie śluzu szyjkowego nie zapobiega przedostaniu się wszystkich plemników do jajowodów. Spowalnianie ruchu jajowodów utrudnia przedostawanie się plemników, ale nie wyklucza tego całkowicie. Powoduje natomiast opóźnienie w dotarciu zapłodnionej komórki jajowej do macicy, przez co przyczynia się do obumarcia zarodka. Niedopuszczenie do zagnieżdżenia jest działaniem niszczącym zapłodnioną komórkę jajową i ma miejsce od kilku do kilkunastu dni po połączeniu komórki jajowej z plemnikiem. Ta błędna odpowiedź została zakreślona przez 23,7\% bada- 
nych. Największą grupę stanowią osoby, które zakreśliły odpowiedź „trudno powiedzieć".

Tabela 2

\begin{tabular}{|l|c|c|}
\hline \multirow{2}{*}{$\begin{array}{c}\text { Które z poniższych sposobów działania antykoncepcji hormonalnej } \\
\text { zapobiegają połączeniu komórki jajowej z plemnikiem }\end{array}$} & \multicolumn{2}{|c|}{ Odpowiedzi } \\
\cline { 2 - 3 } & częstość & procent \\
\hline Zapobieganie owulacji & 231 & 19,7 \\
\hline Zagęszczanie śluzu szyjkowego & 97 & 8,3 \\
\hline Spowalnianie ruchu jajowodów & 43 & 3,7 \\
\hline Niedopuszczenie do zagnieżdżenia zarodka w macicy & 278 & 23,7 \\
\hline Trudno powiedzieć & 481 & 41,1 \\
\hline Odmowa odpowiedzi & 41 & 3,5 \\
\hline Ogółem & $1171^{*}$ & 100,0 \\
\hline
\end{tabular}

*Wyniki nie sumują się do 1046, gdyż respondent mógł wybrać więcej niż jedną odpowiedź.

Tabela 3

\begin{tabular}{|c|c|c|}
\hline \multirow{2}{*}{$\begin{array}{l}\text { Które stwierdzenie na temat antykoncepcji hormonalnej jest, Pani(a) } \\
\text { zdaniem, prawdziwe? }\end{array}$} & \multicolumn{2}{|c|}{ Odpowiedzi } \\
\hline & częstość & procent \\
\hline $\begin{array}{l}\text { Polega wyłącznie na niedopuszczeniu do połączenia komórki jajowej } \\
\text { z plemnikiem }\end{array}$ & 216 & 20,7 \\
\hline $\begin{array}{l}\text { Polega na niedopuszczeniu do połączenia komórki jajowej } \\
\text { z plemnikiem, a jeśli ten mechanizm nie zadziała, środki } \\
\text { uniemożliwiają zagnieżdżenie się zapłodnionej komórki jajowej } \\
\text { w macicy i powodują obumarcie zarodka (6-11 dni od zapłodnienia) }\end{array}$ & 95 & 9,1 \\
\hline $\begin{array}{l}\text { Są różne metody antykoncepcji hormonalnej - część środków } \\
\text { hormonalnych działa tak jak te opisane w punkcie } 1 \text {, inne zaś tak jak } \\
\text { opisane w punkcie } 2\end{array}$ & 357 & 34,1 \\
\hline Trudno powiedzieć & 343 & 32,8 \\
\hline Odmowa odpowiedzi & 35 & 3,4 \\
\hline Ogółem & 1046 & 100 \\
\hline
\end{tabular}

Prawidłową odpowiedź zakreśliło jedynie 9,1\% respondentów. Aż 20,7\% społeczeństwa jest przekonana, że antykoncepcja hormonalna polega tylko i wyłącznie na niedopuszczeniu do połączenia komórki jajowej z plemnikiem, co by oznaczało brak działania wczesnoporonnego tych środków farmakologicznych. Nie jest to jednak odpowiedź zgodna z faktami. 
Tabela 4

\begin{tabular}{|l|c|c|}
\hline \multicolumn{1}{|c|}{$\begin{array}{c}\text { Jakich środków antykoncepcyjnych - mówimy cały czas } \\
\text { o antykoncepcji hormonalnej - jest na rynku więcej? }\end{array}$} & \multicolumn{2}{c|}{ Odpowiedzi } \\
\cline { 2 - 3 } & częstość & procent \\
\hline $\begin{array}{l}\text { Więcej jest takich, które nie dopuszczają do połączenia komórki } \\
\text { jajowej z plemnikiem }\end{array}$ & 208 & 19,9 \\
\hline $\begin{array}{l}\text { Więcej jest takich, które nie dopuszczają do połączenia komórki } \\
\text { jajowej z plemnikiem, a jeśli ten mechanizm nie zadziała, środki } \\
\text { uniemożliwiają zagnieżdżenie się zapłodnionej komórki jajowej } \\
\text { w macicy i powodują obumarcie zarodka }\end{array}$ & 69 & 6,6 \\
\hline Jest ich mniej więcej tyle samo & 236 & 22,6 \\
\hline Trudno powiedzieć & 495 & 47,3 \\
\hline Odmowa odpowiedzi & 38 & 3,6 \\
\hline Ogółem & 1046 & 100,0 \\
\hline
\end{tabular}

Jest to kolejne pytanie, które odsłoniło słabą wiedzę społeczeństwa na temat środków antykoncepcyjnych. Prawdopodobnie wszystkie środki hormonalne oddziałują na zapłodnioną komórkę jajową, przyczyniając się do jej obumarcia. Jeśli istnieją jakieś środki hormonalne o działaniu tylko przeciwpoczęciowym, to jest ich niewiele. Prawidłowa jest zatem odpowiedź numer 2 zakreślona jedynie przez $6,6 \%$ respondentów.

\section{Tabela 5}

\begin{tabular}{|l|c|c|}
\hline $\begin{array}{c}\text { Istnieją dwie definicje ciąży: pierwsza mówi, że ciąża zaczyna się } \\
\text { w momencie zapłodnienia komórki jajowej, druga o tym, że ciąża } \\
\text { zaczyna się w momencie zagnieżdżenia zapłodnionej komórki } \\
\text { jajowej w macicy (6-11 dzień od zapłodnienia). Która z tych definicji } \\
\text { bliższa jest Pana(i) przekonaniom? }\end{array}$ & Częstośćć & Procent \\
\hline $\begin{array}{l}\text { Pierwsza (ciąża zaczyna się w momencie zapłodnienia komórki } \\
\text { jajowej) }\end{array}$ & 521 & 49,8 \\
\hline $\begin{array}{l}\text { Druga (ciąża zaczyna się w momencie zagnieżdżenia zapłodnionej } \\
\text { komórki jajowej w macicy) }\end{array}$ & 330 & 31,5 \\
\hline Trudno powiedzieć & 171 & 16,4 \\
\hline Odmowa odpowiedzi & 24 & 2,3 \\
\hline Ogółem & 1046 & 100,0 \\
\hline
\end{tabular}

Blisko połowa respondentów, czyli 49,8\% uważa za początek ciąży w moment poczęcia, 31,5\% - moment zagnieżdżenia zapłodnionej komórki jajowej w macicy. Odsetek Polaków uznających moment poczęcia za początek ciąży jest bardzo wysoki. 
Tabela 6

\begin{tabular}{|l|c|c|}
\hline \multicolumn{1}{|c|}{$\begin{array}{c}\text { Którą, Pana(i) zdaniem, definicję stosują producenci } \\
\text { antykoncepcyjnych środków hormonalnych? }\end{array}$} & \multicolumn{2}{c|}{ Odpowiedzi } \\
\cline { 2 - 3 } & procent & częstość \\
\hline $\begin{array}{l}\text { Na ogół pierwszą (ciąża zaczyna się w momencie zapłodnienia } \\
\text { komórki jajowej) }\end{array}$ & 331 & 31,6 \\
\hline $\begin{array}{l}\text { Na ogół drugą (ciąża zaczyna się w momencie zagnieżdżenia } \\
\text { zapłodnionej komórki jajowej w macicy) }\end{array}$ & 288 & 27,5 \\
\hline Trudno powiedzieć & 396 & 37,8 \\
\hline Odmowa odpowiedzi & 32 & 3,0 \\
\hline Ogółem & 1046 & 100,0 \\
\hline
\end{tabular}

Świadomość prawdy na temat definicji ciąży stosowanej przez producentów środków antykoncepcyjnych ma 27,5\%, czyli mniej niż jedna trzecia respondentów. Zestawienie tych odpowiedzi z wynikami innych pytań postawionych w badaniu wskazuje jednak, że nawet świadomość definicji ciąży stosowanej $\mathrm{w}$ tych substancjach nie gwarantuje rozumienia ich działania wczesnoporonnego. Prawidłowe rozumienie działania antykoncepcji hormonalnej wykazuje $6,6 \%$ (por. tabela 4) do 9,1\% (por. tabela 3) Polaków.

Tabela 7

\begin{tabular}{|l|c|c|}
\hline $\begin{array}{c}\text { Czy wcześniej, przed naszym spotkaniem słyszał(a) Pan(i) o dwóch } \\
\text { różnych definicjach ciąży stosowanych w thumaczeniu zjawisk } \\
\text { antykoncepcji i wczesnego poronienia? }\end{array}$ & \multicolumn{2}{|c|}{ Odpowiedzi } \\
\cline { 2 - 3 } $\begin{array}{l}\text { częstość } \\
\text { Tak }\end{array}$ & 367 & procent \\
\hline Nie & 637 & 60,9 \\
\hline Odmowa odpowiedzi & 43 & 4,1 \\
\hline Ogółem & 1046 & 100,0 \\
\hline
\end{tabular}

Prawie dwie trzecie Polaków (60,9\%) nigdy nie słyszało o dwóch różnych definicjach pojęć ciąży i wczesnego poronienia. Pokazuje to skalę dezinformacji narodu polskiego w tej dziedzinie.

Aż 47,4\% respondentów, czyli prawie połowa badanych nie chce stosować środków wczesnoporonnych. Szczególnie ważne jest jednak, jak na tę sprawę zapatrują się osoby, które stosują antykoncepcję hormonalną.

Analiza tego problemu została przedstawiona w tabeli 9. W grupie kobiet stosujących antykoncepcję hormonalną w okresie 12 miesięcy przed badaniem odsetek ten wyniósł 45,3\%. Tak duża część kobiet stosujących antykoncep- 
cję hormonalną zadeklarowała zaprzestanie jej stosowania, gdyby dowiedziała się, że działa ona wczesnoporonnie. Oznacza to, że sprzedaż tych środków farmakologicznych spadłaby blisko o połowę, gdyby społeczeństwo znało prawdę na temat ich działania.

Tabela 8

\begin{tabular}{|l|c|c|}
\hline \begin{tabular}{c} 
Na to pytanie proszę odpowiedzieć niezależnie od tego, czy prowadzi \\
Pan(i) życie seksualne. Gdyby dowiedział(a) się Pan(i) o tym, że \\
stosowana przez Panią | Pana partnerkę metoda antykoncepcji \\
powoduje m.in. uniemożliwienie rozwoju ciąży poprzez \\
\cline { 2 - 3 } $\begin{array}{c}\text { niedopuszczenie do zagnieżdżenia zarodka w macicy (niektórzy } \\
\text { uważają to za działanie wczesnoporonne), to czy: }\end{array}$
\end{tabular} & częstośćć & procent \\
\hline Starał(a)by się Pan(i) zaprzestać stosowania tej metody & 495 & 47,4 \\
\hline Nie, nadal stosował(a)by Pan(i) tę metodę & 219 & 21,0 \\
\hline Trudno powiedzieć & 267 & 25,6 \\
\hline Odmowa odpowiedzi & 64 & 6,1 \\
\hline Ogółem & 1046 & 100,0 \\
\hline
\end{tabular}

Społeczeństwo polskie jest przychylne antykoncepcji hormonalnej. Przykładowo badanie CBOS z 2015 roku wykazało, że 72\% społeczeństwa uważa, że Kościół powinien zgodzić się na stosowanie środków antykoncepcyjnych. Niniejsze analizy pokazują jednak, że poparcie społeczne jest wyrażane nie wobec środków sprzedawanych w aptekach, tylko względem pewnej fikcji marketingowej. Ludzie popierają oszustwo, którego nie są świadomi ${ }^{2}$.

Tabele 10 i 11 pokazują analizę postawy Polaków wobec problematyki przejrzystości przekazu na temat wczesnoporonnego działania produktów wprowadzanych do obrotu. Odpowiedzi na te pytania odsłaniają skalę braku akceptacji dla matactw informacyjnych wokół wczesnoporonnego działania wszelkich substancji sprzedawanych na rynku.

\footnotetext{
${ }^{2}$ https://www.cbos.pl/SPISKOM.POL/2015/K_032_15.PDF [dostęp: 01.09.2018].
} 


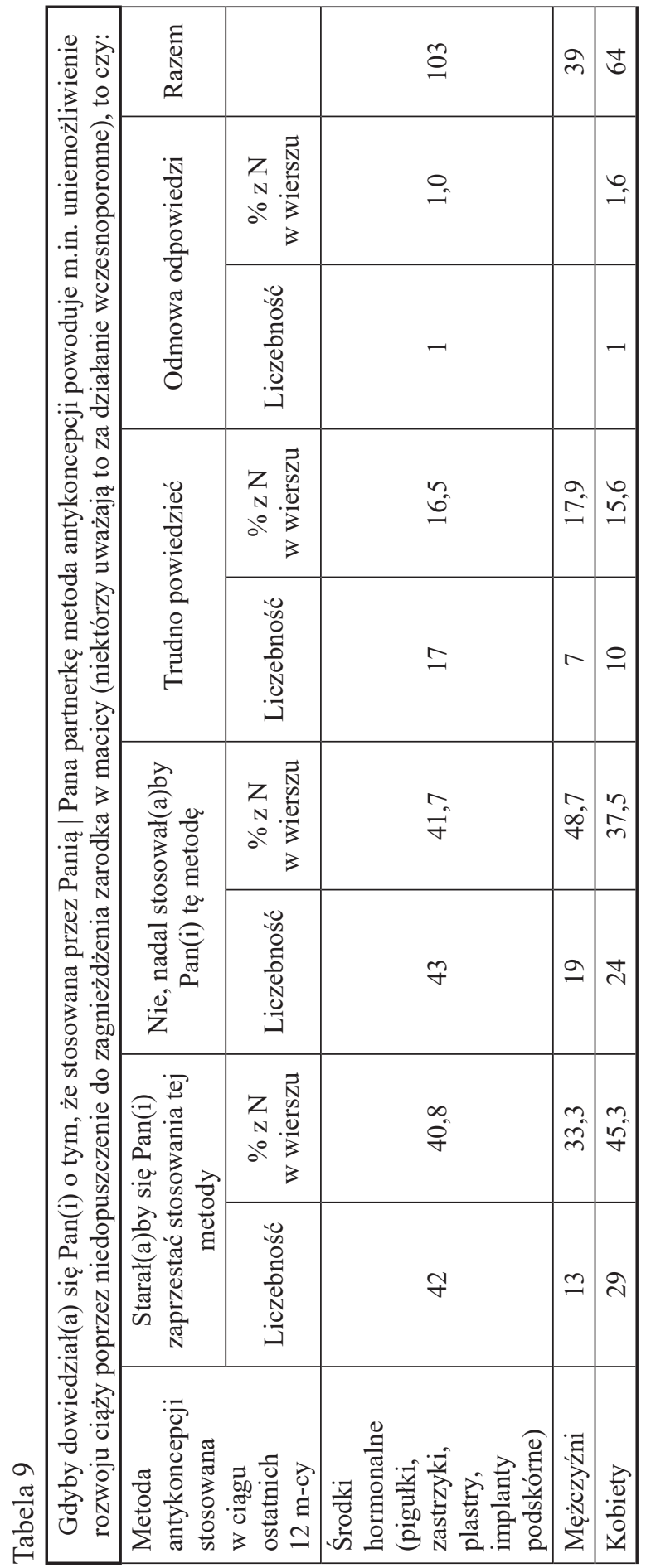


Tabela 10

\begin{tabular}{|l|c|c|}
\hline \multirow{2}{*}{$\begin{array}{c}\text { Czy, Pana(i) zdaniem, informacja o możliwym działaniu } \\
\text { wczesnoporonnym wszelkich produktów dostępnych na rynku } \\
\text { powinna być wyraźnie prezentowana konsumentom przed ich } \\
\text { zastosowaniem, np. na ulotce, opakowaniu, w momencie zakupu, } \\
\text { przepisywania recepty, w przekazie medialnym? }\end{array}$} & Odpowiedzi \\
\cline { 2 - 3 } $\begin{array}{l}\text { częstość } \\
\text { Tak }\end{array}$ & procent \\
\hline Nie & 834 & 79,7 \\
\hline Trudno powiedzieć & 92 & 8,8 \\
\hline Odmowa odpowiedzi & 86 & 8,2 \\
\hline Ogółem & 35 & 3,3 \\
\hline
\end{tabular}

Prawie $80 \%$ respondentów twierdzi, że informacja o możliwym działaniu wczesnoporonnym powinna być uczciwie prezentowana przed zakupem we wszelkich miejscach przekazu (por. tabela 10). W grupie kobiet stosujących antykoncepcję hormonalną 12 miesięcy przed badaniem odsetek osób o takich poglądach był jeszcze wyższy i wyniósł 90,5\% (por. tabela 11).

Tabela 11

Czy, Pana(i) zdaniem, informacja o możliwym działaniu wczesnoporonnym wszelkich produktów dostępnych na rynku powinna być wyraźnie prezentowana konsumentom przed ich zastosowaniem, np. na ulotce, opakowaniu, w momencie zakupu, przepisywania recepty, w przekazie medialnym?

\begin{tabular}{|l|c|c|c|c|c|c|}
\hline \multirow{2}{*}{$\begin{array}{l}\text { Metoda } \\
\text { antykoncepcji } \\
\text { stosowana w ciągu } \\
\text { ostatnich 12 m-cy }\end{array}$} & \multicolumn{2}{|c|}{ Tak } & \multicolumn{2}{c|}{ Nie } & \multicolumn{2}{c|}{ Trudno powiedzieć } \\
\cline { 2 - 7 } & liczebność & $\begin{array}{c}\text { \% z N } \\
\text { w wierszu }\end{array}$ & liczebność & $\begin{array}{c}\% \text { z N } \\
\text { w wierszu }\end{array}$ & liczebność & $\begin{array}{c}\% \text { z N } \\
\text { w wierszu }\end{array}$ \\
\hline $\begin{array}{l}\text { Środki hormonalne } \\
\text { (pigułki, zastrzyki, } \\
\text { plastry, implanty } \\
\text { podskórne) }\end{array}$ & 91 & 90,1 & 8 & 7,9 & 2 & 2,0 \\
\hline Mężczyźni & 34 & 89,5 & 2 & 5,3 & 2 & 5,3 \\
\hline Kobiety & 57 & 90,5 & 6 & 9,5 & & \\
\hline
\end{tabular}

Zamieszczone analizy i badania wskazują, że poprzez zmianę definicji ciąży oraz sposób informowania świadomie oszukano społeczeństwo. Doprowadzono do milionów wczesnych aborcji bez zgody, wiedzy i akceptacji kobiet. Poparcie społeczne dla środków antykoncepcyjnych zbudowano na oszustwie i manipulacji. 
Matactwa nie byłyby konieczne, gdyby ludzie akceptowali prawdę na temat działania antykoncepcji hormonalnej, o czym odpowiednie grupy interesu prawdopodobnie wiedziały od początku wprowadzania ich na rynek, czyli od lat 60 .

Skuteczne odsłonięcie prawdy przeprowadzone na większą skalę prawdopodobnie nie tylko spowodowałoby znaczący spadek sprzedaży antykoncepcji hormonalnej, ale również uruchomiłoby szereg konsekwencji prawnych. Oprócz praw do odszkodowań ludzie mogliby zacząć rozważać aspekty karne. W art. 153 kodeksu karnego czytamy przykładowo3 ${ }^{3}$ :

$\S 1$. Kto stosując przemoc wobec kobiety ciężarnej lub w inny sposób bez jej zgody przerywa ciążę albo przemocą, groźbą bezprawną lub podstępem doprowadza kobietę ciężarną do przerwania ciąży, podlega karze pozbawienia wolności od 6 miesięcy do lat 8 .

$\S 2$. Kto dopuszcza się czynu określonego w $\S 1$, gdy dziecko poczęte osiągnęło zdolność do samodzielnego życia poza organizmem kobiety ciężarnej, podlega karze pozbawienia wolności od roku do lat 10.

Kodeks karny wyraźnie posługuje się pojęciem „poczęte dziecko”, wskazując na poczęcie jako początek życia dziecka. Nie ma wątpliwości, że do wczesnych aborcji bez zgody i wiedzy kobiet doszło poprzez zastosowanie podstępu. Uczestniczyły w nim liczne środowiska zainteresowane finansowo tym, aby prawda nie była powszechnie znana.

\section{Presja grup interesu w sprawie antykoncepcji hormonalnej}

Analiza procesów informacyjnych wskazuje, że do oszustwa wobec kobiet doprowadziły działania licznych grup interesu. Można wśród nich wymienić między innymi media mainstreamowe, lekarzy ginekologów, farmaceutów, środowiska akademickie, działaczy politycznych, społecznych, ludzi związanych ze światem kultury i przemysłem rozrywkowym. Poniższe analizy tłumaczą pokrótce uwikłanie finansowe różnych grup w problematykę promocji antykoncepcji hormonalnej.

\footnotetext{
${ }^{3}$ Ustawa z dnia 6 czerwca 1997 r. - Kodeks karny, Dz.U. 1997 nr 88 poz. 553, art. 153.
} 


\section{Media mainstreamowe}

Media są utrzymywane w dużej mierze przez reklamodawców, czyli przede wszystkim przez wielki biznes. Liczne potężne koncerny globalne zarabiają ogromne pieniądze na zjawiskach i produktach krytykowanych przez Kościół katolicki, takich jak: antykoncepcja, aborcja, homoseksualizm, in vitro, transseksualizm, treści erotyczne, papierosy i in. W okresie 2013-2015 reklamodawcy propagujący wyżej wymienione treści mieli średnio 22,06\% udziału w wydatkach na reklamy w mediach w Polsce, natomiast podmioty związane z Kościołem katolickim jedynie 0,16\%. Wykres 1 pokazuje te proporcje dla roku 2015.

Wykres 1. Udział wydatków reklamodawców liberalnych i religijnych w ogóle wydatków reklamowych w 2015 roku



Źródło: Opracowanie własne na podstawie danych monitoringu rynku reklamy firmy Kantar Media Sp. z o.o.

Producenci środków antykoncepcji hormonalnej płacili mediom w okresie 2010-2015 średnio 10-krotność kwot wpłacanych przez reklamodawców związanych z Kościołem katolickim.

Ponadto obserwuje się zjawisko nierównego traktowania mediów przez reklamodawców. Firmy faworyzują media, których przekaz jest zgodny z ich interesami. Sprzedawcy produktów antykoncepcyjnych wykupują reklamy przede wszystkim w mediach lewicowych, które przekazują społeczeństwu 
to, czego oczekują reklamodawcy. Tworzenie mętnego obrazu działania tych środków jest zatem opłacalne dla mediów. Przyciąga to bowiem bogatych reklamodawców i skutkuje lepszymi wynikami ekonomicznymi.

O dominującym sposobie przekazu ośrodków informacyjnych nie decyduje zatem prawda i obiektywna analiza faktów, ale uwikłania finansowe i konflikty interesów spółek medialnych. Uruchamia to szereg dalszych konsekwencji, na przykład promowanie głównie lewicowych partii politycznych wygodnych wielkiemu biznesowi, popieranie i otaczanie ochroną decyzji politycznych sprzyjających interesom potężnych koncernów. Do takich ochranianych decyzji należała między innymi zmiana definicji pojęcia „ciąża” na taką, która wspiera sprzedawców antykoncepcji hormonalnej.

\section{Lekarze ginekolodzy, farmaceuci}

W prywatnych gabinetach liczni lekarze ginekolodzy zarabiają na przepisywaniu recept na antykoncepcję hormonalną. Farmaceuci uczestniczą w jej dystrybucji i sprzedaży. Lekarze i farmaceuci, którzy podkreślają prawdziwe działanie tych substancji, spotykają się z obstrukcją we własnym środowisku zawodowym oraz ze strony innych grup interesu.

\section{3. Środowiska akademickie}

Medyczne środowiska akademickie są uzależnione od opinii recenzentów, wśród których ogromna grupa zarabia w prywatnych gabinetach na przepisywaniu recept na antykoncepcję hormonalną, współpracy z antykoncepcyjnym biznesem farmaceutycznym lub w inny sposób odnosi korzyści finansowe wynikające $\mathrm{z}$ propagowania liberalizmu światopoglądowego. Wyższe uczelnie nie są zatem chętne do nagłaśniania prawdy niewygodnej dla części pracowników naukowych.

\section{Politycy, dzialacze, społeczni, ludzie związani ze światem kultury i przemysłem rozrywkowym}

Poprzez wyrażanie poglądów propagujących interesy wielkiego biznesu przedstawiciele takich zawodów uzyskują ochronę mediów mainstreamowych. Wpływa to pozytywnie na ich sytuację społeczną i finansową. Przykładowo otaczani życzliwością większości mediów liberalni politycy mają większe szanse w wyborach i dostęp do wysoko opłacanych stanowisk pań- 
stwowych. Aktorzy są otaczani większą życzliwością, co skutkuje uzyskiwaniem lepszych propozycji filmowych. Muzycy dzięki przychylności mediów są lepiej promowani, dzięki czemu zarabiają więcej na swojej twórczości.

Zmiana definicji pojęcia „ciąża” zbiegła się w czasie z wprowadzeniem na rynek antykoncepcji hormonalnej i niewątpliwie miała z tym związek. Dzięki temu można było stworzyć machinę marketingową i zapewnić gigantyczne zarobki firmom farmaceutycznym - producentom antykoncepcji hormonalnej, a także innym grupom interesu. Modyfikacja definicji niemal natychmiast po wprowadzeniu wynalazku na rynek świadczy o tym, że liczne środowiska miały pełną świadomość dotyczącą prawdziwego mechanizmu działania tych substancji. Od początku wiadomo było, że zgodne z prawdą przedstawienie sposobu działania wspomnianych środków uniemożliwiłoby skuteczną sprzedaż.

Zmiana definicji ciąży wiązała się z zamiarem osiągnięcia korzyści marketingowych, do czego konieczne było mataczenie wokół prawdy o antykoncepcji hormonalnej i wprowadzanie kobiet w błąd. Uczestniczyli w tym nie tylko producenci, ale również media, politycy, członkowie towarzystw ginekologicznych oraz WHO, prawdopodobnie z uwagi na dochodowość tych produktów dla branży medycznej i samych lekarzy. Antykoncepcja hormonalna wymaga wypisywania recept i kontroli lekarza, co związało pacjentki z ginekologami uzyskującymi niemałe przychody za obowiązkowe wizyty.

Skoro można przez lata bezkarnie zezwalać na miliony wczesnych aborcji bez zgody i wiedzy kobiet, to należy zadać pytanie o prawdziwe mechanizmy ustroju państwowego. Głębsza analiza pokazuje, że dostosowanie dominującego przekazu do potrzeb sprzedażowych wielkiego biznesu jest powszechną praktyką mediów. W wielu ważnych sferach przekazywanie wiedzy dostosowane do oczekiwań wielkiego biznesu nie jest wyjątkiem od reguły, ale obowiązującą zasadą działania. Podporządkowanie interesom koncernów stało się normą na licznych obszarach funkcjonowania państwa. Problemy te można skutecznie rozwiązać w dużej mierze poprzez zmianę systemu, czyli działania na gruncie prawnym. Prawo powinno lepiej regulować procesy informacyjne oraz chronić obywateli przed oszustwami i podstępami grup interesu. 


\title{
INFLUENCE OF ECONOMIC PHENOMENA ON DISTURBING PROCES- SES OF INFORMATION ON THE FUNCTIONING AND EFFECTIVENESS OF HORMONAL CONTRACEPTION
}

\begin{abstract}
When Pope Paul VI in the encyclical Humanae vitae rejected the support for new products of hormonal contraception, it aroused misunderstanding in many circles, also within the Catholic Church. Years later, however, new facts emerge, the meaning of which is better known today than years ago. In 1965, the definition of pregnancy was changed to one that conceals the abortional influence of these substances. On the basis of contemporary research, it turns out that for over 50 years, public opinion about the true effect of hormonal contraception has been cheated. The confusion of information in the public space around this matter is enormous.

A survey conducted in Polish society by the Public Opinion Research Center in 2014 showed a great ignorance of Poles about the true effect of hormonal contraception. It turns out that millions of early miscarriages have been brought without the consent and knowledge of women. This was accomplished by numerous interest groups financially interested in the truth being not widely known. The circles involved in this scam include leading representatives of mainstream media, gynecologists, pharmacists, academics, political and social activists, people associated with the world of culture and the entertainment industry.

There is a need for changes in the law that will protect citizens against dishonest market practices in terms of conflicts of interest and corruption.
\end{abstract}

Keywords: Humanae vitae; contraception; corruption; conflict of interest; advertising market

Słowa kluczowe: Humanae vitae; antykoncepcja; korupcja; konflikt interesów; rynek reklamy

\section{BIBLIOGRAFIA}

Encyklika Ojca Świętego Pawła VI Humanae vitae - O zasadach moralnych w dziedzinie przekazywania życia ludzkiego (25.07.1968). https://opoka.org.pl/biblioteka/W/WP/pawel_vi/encykliki/ humane.html [dostęp: 01.09.2018 r.].

Jarczewska D.Ł., Barczentewicz M. (2015), Czy doustne środki antykoncepcyjne działaja po zapłodnieniu ? w: Szkodliwość doustnej antykoncepcji hormonalnej, red. D.Ł. Jarczewska, Warszawa, s. 3-36.

Jarczewska D.Ł. red. (2015), Szkodliwość doustnej antykoncepcji hormonalnej, Warszawa.

Prusak M. (2015), Informacje o mechanizmach działania tabletek antykoncepcyjnych przedstawiane w ulotkach dla pacjentek w: Szkodliwość doustnej antykoncepcji hormonalnej, red. D.Ł. Jarczewska, Warszawa, s. 37-43. 
Ustawa z dnia 6 czerwca 1997 r., w: Kodeks karny, Dz.U. 1997 nr 88 poz. 553. https://www.cbos.pl/SPISKOM.POL/2015/K_032_15.PDF [dostęp: 01.09.2018].

pl.pons.com [dostęp: 01.09.2018].

www.myfertiledays.com [dostęp: 01.09.2018].

Natalia Zimniewicz - doktor nauk ekonomicznych, specjalizuje się w problematyce finansów przedsiębiorstw, korupcji. Prowadzi badania na temat nieuczciwych praktyk rynkowych jednostek ekonomicznych związanych z zagadnieniami światopoglądowymi m.in. aborcją, gender czy antykoncepcją. 